\title{
NOT ONLY THE POLISH PEASANT. ZNANIECKI'S POZNAŃ SCHOOL OF SOCIOLOGY AS A SOCIOLOGICAL AND A RESEARCH ISSUE ${ }^{1}$
}

\begin{abstract}
Just like Émile Durkheim in Bordeaux, Florian Znaniecki established in Poznań his own School of Sociology. By referring to the school, it is meant educational, research, academic and organisational activities on the part of F. Znaniecki and his co-workers in 1920-1939, undertaken primarily in two institutions: the Poznań University and the Polish Institute of Sociology established also in Poznań. While the city was the heart of the School's operations, its influence was much stronger. This was reflected in the initiatives which integrated various sociological circles in Poland, maintaining contacts with other academic centres, specifically in the US, engaging in academic work or establishing own research institutes in new locations in Poland and abroad by Znaniecki's disciples.

The article indicates selected major characteristics of the Poznań School of Sociology including the adoption of a specific viewpoint represented by Znaniecki about sociology and forging closer bonds between him and his disciples. In the final part, the article indicates certain detailed issues which, when explained, would let us better understand the nature of the development
\end{abstract}

PhD, Faculty of Sociology; e-mail: j.kubera@amu.edu.pl; https://orcid.org/0000-0003-1513-1639

1 The author acknowledges the financial support of the French Government and the French Embassy in Poland. 
of Znaniecki's school and, in a broader approach, Polish sociology and its relations with European and American sociology.

Keywords: schools of sociological thought, history of sociology, Florian Znaniecki, Polish sociology, Poznań

\section{INTRODUCTION}

Just like Émile Durkheim in Bordeaux, Florian Znaniecki established in Poznań his own school of sociology. The main goal of this article is to juxtapose the teaching, research, academic and organisational activity of Znaniecki and his colleagues in 1920-1939 with indices mentioned in sociological literature which refer to a phenomenon of a school of thought [e.g. Harvey 1987; Szacki 1975; Muszyński 1995; Hirschhorn 2018]. These indices are generalisations, most frequently drawn from analyses of cases of groupings of academics and researchers recognised by sociology historians like Durkheim's School, the Chicago School, the Frankfurt School and others [Clark 1968; Besnard 1979; Bulmer 1984; Harvey 1986]. Typically, they are not treated like universal or strict criteria but rather like useful tools for delimitation of a specific school of thought. This stems from both the diversity of the various historical cases and the diversity of opinions in sociology on what the schools are and what role they play in developing scientific knowledge [Hirschhorn 2018; Harvey 1987]. The most frequently mentioned elements contributing to the phenomenon include the emergence of a relatively small grouping (or cluster) of practitioners in a specific discipline, circumstances conducive to the grouping's emergence and development, presence of a founder or leader, master-disciples relations, close and frequent contacts between the members, adoption of a specific way of practising the discipline, awareness of own autonomy, establishment of a myth or a legend of the school.

While many publications include the same information that a school of sociology was established in Poznań [e.g. Czarnocki, Kwilecki 1989, 8-9], it has not been appropriately studied to provide answers to the questions about the scale and nature of Znaniecki's impact on his disciples. For this reason, the second goal of this article is to shed light on Znaniecki's Poznań School as a sociological issue worth initiating separate research. Of course, a lot has been done in this respect, especially in the realm of Znaniecki's activity and his sociological theories [e.g. Hałas 2000; Hałas 2006; Dulczewski 1986], the history of sociology in Poznań [e.g. Kwilecki, Ziółkowski 1981, Kowalski, Włodarek 1970; Lisiecki, Kubera 2016] and in Poland in general [e.g. Kraśko 1996; Kraśko 2010; Kwilecki 
1988; Ruszczewska 1990; Bucholc 2016]. Notably, Zygmunt Dulczewski's book written following numerous queries [see: 1984: 16-18], which is now the major source of knowledge on the academic biography of the co-author of The Polish Peasant, was intended to be one of three. Volume two was to include the systematics and criticism of Znaniecki's achievements in sociology; to a large extent, the goal has been achieved [Hałas 2010b and others]. The third volume was to present exhaustingly the reception and Znaniecki's school. This work still needs to be done although some random attempts have already been made [Wojtczak et al. 1992; Lisiecki 2015; Kubera, Skoczylas, Szerksznis 2017].

In the subsequent three parts of the article, I attempt to indicate selected major characteristics of the Poznań School of Sociology including adoption of a specific viewpoint represented by Znaniecki on the subject and scope of sociology, forging closer bonds between him and his disciples, tolerance of different scholarly views, contributing to the formation of academic sociology and integration of sociological circles in Poland, maintaining contacts with other sociology centres outside of Poland and continuing research traditions, established in Poznan, in various centres in Poland and in the world. In the final part of the article, I make some generalisations and indicate certain detailed issues which, when explained, would let us better understand the nature of the development of Znaniecki's school and, in a broader approach, Polish sociology and its relations with European and American sociology [see: Kwaśniewicz 2001; Mucha 2009; Wiley 2007].

\section{ESTABLISHMENT OF A NEW SCHOOL}

Interestingly, while many illustrious scholars in Poland and other countries have played an important role in the academic development of their younger colleagues, especially in the universities, not always did it lead to establishing a new school of thought. In the case of the Poznan School, several factors were at play simultaneously. One of these was, undoubtedly, the unquestioned scholarly authority of Znaniecki, co-author of the famous monograph The Polish Peasant in Europe and America (1918-1920), a former teacher at the Department of Sociology at the University of Chicago.

Before Znaniecki started cooperation with William I. Thomas, he had studied at the University of Geneva (1905-1907), the University of Zurich (1907-1908; he listened to lectures by educator Friedrich Wilhelm Foerster and psychologist Gustav Wilhelm Störring) and the Sorbonne in Paris (between October 1908 and March 1909; there, he developed more interest in sociology, participated in classes conducted by Frédéric Rauh, Émile Durkheim, André Lalande and Lucien 
Lévy-Bruhl) [Dulczewski 1984: 37-47]. Under the academic supervision of Frédéric Rauh, he started to write a doctoral thesis The Idea of Honour among the French Gentry, never finished because of the promoter's death. Following his return from France, Znaniecki studied for one semester (1909) at the Faculty of Philosophy at Jagiellonian University in Krakow (his teachers included Maurycy Straszewski, Stefan Pawlicki and Władysław Heinrich) where in 1910, he defended a doctoral thesis on Zagadnienie wartości w filozofii [The Problem of Values in Philosophy] [Dulczewski 1984: 48-55]. Later, he was active in Warsaw as part of the Polish Psychological Society (1910-1914). He acquainted himself with Polish migration as a librarian in the Polish Museum in Rapperswil, Switzerland (when he was a student in Zurich) and as director of the Emigration Protective Association in Warsaw (1910-1914). F. Znaniecki was not only very knowledgeable about the latest trends in philosophy and sociology but also had strong theoretical views [Hałas 2010b: 108-113]. In his books, articles and reviews published before 1914, he often included sociological considerations; he was critical of Herbert Spencer's definition of social reality and other organicistic theories, about social psychology (predominantly Wilhelm Wundt) and Durkheim's School. However, he spoke highly of Henri Bergson's ideas; Znaniecki translated his Creative Evolution into Polish in 1913 [Dulczewski 1984: 76-95].

In the United States (1914-1920), Znaniecki got insight into the famous Department of Sociology at Chicago [see: Bulmer 1984: 45-63; Wallis 1989; Benisz 2013]. He also acquainted himself with the various trends in American sociology and gained an appreciation of empirical studies. When he was leaving Poland for America, he probably did not plan to continue his philosophical career in his homeland (hence the publication in English of Cultural Reality in 1919, methodologically close to the "Methodological Note" to The Polish Peasant). When he left the US, he was perceived mostly as a sociologist and he started to consider himself a sociologist as evidenced by his subsequent scholarly activity [Dulczewski 1984: 186-190; Znaniecki Lopata 1976: 208-209].

In early 1920, Znaniecki returned to Poland with an intention of finding employment in a university and thus contribute to restoring the state which regained independence after WWI (back then, in a letter to the Polish authorities, he planned to establish a national Institute of Sociology as he was afraid of being denied a job in a department of sociology; the Institute would collect and develop sociological materials and would educate sociologists) [Dulczewski 1984: 207-209]. As the newly organized Poznan University replied to Znaniecki's enquiry faster than Jagiellonian University, he moved to Poznań for almost twenty years. In March 1920, he became head of the Department of Philosophy III (at his request, rena- 
med the Department of Sociology and Philosophy of Culture) as part of which he established the Sociology Seminar that marked the beginning of sociology as an academic discipline in Poland.

The emergence of sociology at a Polish university was conducive to establishing a new school of thought. The classes were to be conducted by a scholar whose understanding of sociology as science was different from the prevailing concepts. For the first time, Poland educated future sociologists in a formal way, as part of university structures. As a result of Znaniecki's influence, Tadeusz Szczurkiewicz and Józef Chałasiński (to name a few) changed discipline at the university and started to study sociology [Wesołowski 1976: 29-30]. On the other hand, hearing the news that a new field of study was established in Poland, Theodore Abel moved from Warsaw to Poznań [Wincławski 2012: 5]. Later, the three of Znaniecki's first students became his closest co-workers. Since 1920, he delivered a series of lectures on basic sociology - three hours a week for four years (including the history of sociology, introduction to sociology, systematic sociology, methodology and education theory of sociological research), monograph courses - two hours a week (e.g. on the inhabitants of Polish villages, on the basis of The Polish Peasant, application of sociology in social practice, national and class solidarity and changes to social relations), classes in sociology - two hours a week (with the goal of the students carrying out single-handedly analyses of nationality, family, marriage, social work) and sociology seminars - two hours a week (dedicated to independent research under the supervision of Znaniecki, typically resulting in doctoral theses, later on doctoral and master's theses). Znaniecki updated the lectures' subjects as his own sociological theory developed and subsequent social studies were conducted in the Polski Instytut Socjologiczny (PIS) [Polish Institute of Sociology] [Dulczewski 1984: 212-217].

During the entire time of his engagement at the Poznań University, Znaniecki lectured in sociology and other disciplines at the Humanities Faculty. His talks, in various years, were attended by 20 to 50 individuals. The academic years of 1931/32 and 1932/33 were exceptions when he was a visiting professor at Columbia University. Until his trip to the US, he also taught sociology at the Faculty of the Law and Economy where his group of students would sometimes amount to 150. According to Dulczewski [1984: 228-229], his student and biographer, Znaniecki's seminars were more elitist, attended typically by around a dozen most advanced students and graduates of mostly sociology and other disciplines: the law, economics, history, pedagogy and philosophy, willing to carry out sociological research. For example, Stanisław Kowalski [1987: 175] first joined the group of Znaniecki's disciples as a student of pedagogy and, later, as a doctoral 
student of sociology. Józef K. Gidyński, a lawyer, became another of Znaniecki's disciples. He contributed greatly to the development of the PIS as an institution [Wesołowski 1976: 30; Dulczewski 1984: 237-239].

The titles of master's, doctoral and habilitation theses written by Znaniecki's students reflected his research interests [Dulczewski 1984: 230]. They were related to history, methodology and theory of sociology, rural sociology, urban sociology, sociology of education, sociology of social strata and classes. Some of these works, articles and books by members of the Poznań School in the Interwar Period were written based on analyses of materials collated by the PIS (e.g. Drogi awansu społecznego robotnika [A Worker's Ways of Social Advancement] by Chałasiński from 1931). By 1939, Znaniecki had promoted seven masters of arts (Jerzy Piotrowski, Władysław Okiński, Eleonora Odlanicka-Poczobutówna, Franciszek Pawuła, Witalis Talejko, Urszula Wenska and Felicja Straszewska), fifteen doctors of philosophy (rev. Józef Moniuszko, Stanisław Orsini-Rosenberg, Józef Chałasiński, rev. Walerian Adamski, Helena Erzepki, rev. Franciszek Mirek, Jan Krzyżanowski, Alfred Merkert, Helena Miller, Zofia Śliwińska, Tadeusz Szczurkiewicz, Wiesław Kryński, Władysław Okiński, Jan Szczepański and Stanisław Kowalski) and three associate professors (rev. Mirek, Chałasiński and Szczurkiewicz) [Dulczewski 1984: 229-230].

Znaniecki's scholarly authority underpinned by his kindness and understanding resulted in friendly relationships between him and his students with whom he would typically launch projects. "The students referred to prof. Znaniecki as Master in conversations, at meetings with students of other disciplines or from other universities during fellow members gatherings, academic sessions, etc.", as Dulczewski pinpointed [1984: 218]. Znaniecki encouraged his students to express critical opinions on the presented content, accepted questions asked during his lectures, approved of smoking during his classes and some of the students addressing him by his first name, clearly adopting American habits. The students attending his seminars and lectures reminisced that Znaniecki had subordinated nearly all his classes to his research and academic work. Kowalski [1987: 175-176] wrote that together with his colleagues, he could follow the professor's creative efforts and expect publications of books whose content had already been known to them. Kowalski admitted that while Znaniecki could be an excellent speaker, for example during public speeches outside of the university, his lectures did not enjoy great popularity because "they were a quest for the expression of thoughts in the making" [1987: 185]. Szczepański [1984: 8] also admitted that Znaniecki did not enjoy an opinion of a fascinating lecturer; his lectures were typically dedicated to his current work. However, his seminars 
and direct contact with him were perceived differently. During his seminars, Znaniecki managed the students' individual work, required formulating own hypotheses and solutions rather than repeating already existing opinions. The seminars were referred to as "very instructive" [Szczepański 1984: 8], "inspiring" and "simply delightful" [Kowalski 1987:185]. He had developed special, private relationships with his closest students: "Master Florian Znaniecki and his students were academic partners linked by a strong bond, familiarity and social relations. Great opportunities availed themselves during meetings and parties following defences of doctoral theses" [Dulczewski 1984: 230].

Over time, especially in the 1930s, an increasing number of classes at the Poznań University was conducted by Znaniecki's disciples who were awarded subsequent academic degrees and titles, among them Mirek, Chałasiński, Okiński, Szczurkiewicz and Ludwika Dobrzyńska-Rybicka who defended her doctoral thesis in Zurich and habilitation thesis on history of philosophy at Jagiellonian University. The classes were also attended by employees of the Sociological Seminar. By 1937, the institution employed Znaniecki as its director plus another person as a junior assistant (formerly a librarian), namely Szczurkiewicz (three years), Wernerowa (one year), rev. Krzyszkowski (two years), Chałasiński (two years), Kryński (four years), Okiński (two years), Szczepański (one year) and Orchowski (two years), Kowalik (one year). Not earlier than in 1937 did Znaniecki manage to obtain two more jobs for the Seminar: senior assistant (occupied first by Szczurkiewicz and in the following year by Szczepański) and an unpaid job of an assistant-volunteer which, however, offered social security and railway reductions (first taken by Orchowski, later on by Wenska) [Dulczewski 1984: 212-213]. The fact that Znaniecki's disciples defended habilitation theses: Mirek (1930), Chałasiński (1931) and Szczurkiewicz (1939), provided the Poznań School with possible reproduction of scientists and was an element of a generation change in Polish sociology [Wincławski 2012: 11-12].

The Poznań School of Sociology relied predominantly on Znaniecki's theory and methodology which he developed in 1920-1939. As for books, he published in Polish Wstep do socjologii [An Introduction to Sociology] (1922), can be acknowledged as a manifesto and a manual of the Poznań School [Wincławski 2012], Socjologia wychowania [The Sociology of Education] (vol. I 1928, vol. II 1930), Miasto $w$ świadomości jego obywateli [The City Viewed by its Inhabitants] (1931, on the basis of replies provided as part of a contest "What does Poznań mean to you?") and, in English, The Laws of Social Psychology (1925), The Method of Sociology (1934) and Social Actions (1936). Since the theoretical system of Znaniecki has already been presented by other authors [see: Hałas 
2010b; Coser 1977: 523-530; Markiewicz-Lagneau 1982], I will focus on the conviction of Znaniecki's disciples that his views differed from the other known trends in sociological theory. This is very distinctly reflected in Mirek's preface to his book Elementy spoleczne parafii rzymskokatolickiej. Wstepp do socjologii parafii [Social elements in a Roman Catholic parish. Introduction to parish sociol$o g y$ ] (1928). Interestingly, the words related to researching religious phenomena were written by a Catholic priest. As a sociologist, following the principle of Znaniecki's humanistic coefficient, he suggested that social reality is what individuals experience rather than what an external researcher perceives:

First and foremost, let me emphasize (...) that it is not a responsibility of sociology to examine the origins or objective contents of religion or the teachings of the Roman Catholic Church. According to the Poznań School of Sociology established by prof. Znaniecki, a sociologist examines values and social deeds already f o u $\mathrm{n} \mathrm{d}$ in the surveyed groups or social units. This indicates that if a sociologist discovers that, for example, members of the Catholic Church recognise Christ as God, the Establisher of the Church, an ideal model, etc., the sociologist will not investigate to what extent all these claims are in se true, to what extent they are justified e.g. by philosophy or history, because this is not the subject matter of sociology. It deals with what the church-goers really think about Christ, to what extent the example of Christ's life affects updating human deeds, in general how "individuals and groups of people experience Christ or come up with as a result of their own actions", possibly also what alien individuals or groups think about the Church, its teachings etc. The results of sociological research may be used by other disciplines, e.g. ethics, politics, pedagogy, to draw substantial conclusions, in the form of certain bans and orders, but sociology per se does not put forward such axiological conclusions [Mirek 1928: 3].

In this context, Mirek wrote about the difference between Znaniecki's School and the schools of thought established by Durkheim and Spencer:

This definition of the subject of sociology determines the major difference between views on religious groups represented by Durkheim's or Spencer's schools of thought and the Poznan School of Sociology. While Durkheim's school of thought had some à priori philosophical assumptions about the essence of religion, e.g. that religion is a function of a social group (É. Durkheim, Les formes élémentaires de la vie religieuses, p. 65), according to Spencer's school of thought, "when describing the beginning and the development of ecclesiastical institutions, we need to describe the beginning and development of religion" (H. Spencer, Ecclesiastical institutions, p. 137). The Poznań School of Sociology did not get involved in philosophical inquiries, leaving them to other disciplines; sociology examines a community as experienced by social objects [Mirek 1928: 3].

\section{Other Znaniecki's disciples also used the notion of "School":}

I was a part of the team of Znaniecki's disciples as a student of pedagogics in the academic years of 1926/1927-1929/1930 and, later, in the 1930s as a doctoral student of sociology (...). I joined the team when Znaniecki worked as a professor in the already operating Department of Sociology at Poznań University. He was extremely popular for a founder of one's own 
system of sociology (...). I joined the team as a student of another discipline of science and yet I felt like I belonged there completely. Everything that was going on there and what as said complemented in a very good way (at the same time strongly contrasting with) what I learnt in my major field of studies. It oriented me towards biologist psychology and normative pedagogy which had already been under the modernistic influence of Znaniecki's school of sociology (...) [Kowalski 1987: 175-176].

In the twenty years that he spent in Poznań, he was a thesis promoter of 15 doctoral students of sociology and organised a team of collaborators typically referred to as "Znaniecki's School" [Dulczewski 2000: 16].

The inner coherence of the Poznan School and its autonomy from Polish sociology was emphasized in reports on meetings attended by scholars from Poznań and other academic centres:

Sociologists representing all the academic centres arrived (...) As expected, the biggest group consisted of Poznan sociologists: the locals and the biggest group in Poland affiliated mainly with prof. Znaniecki. For this reason, a speech delivered by the founder of the Poznan school of sociology was of special interest at the rally. Prof. Znaniecki's disciples, active as the rally speakers, included J. Chałasiński, Ph.D., S. Orsini-Rosenberg, Ph.D., rev. F. Mirek, Ph.D. and L. Dobrzyńska-Rybicka, Ph.D. [Znamierowski 1931: 573-574].

On the other hand, abroad Znaniecki's school was sometimes referred to as the Polish School. A case in point is Lewis A. Coser who recognised it as one of three schools which emerged before and around WW:

The group of sociologists Durkheim brought together in 1898, and who were to stay together and contribute to the "Année Sociologique" until the First World War, was probably the most brilliant ever gathered in the history of the discipline. Initially a loose grouping of collaborators, it soon developed into a closely-knit school (...). The other two schools which have appeared so far in sociology included the Chicago School, created by Albion Small, and composed of such major figures as Robert Park, William I. Thomas, and Ellsworth Faris; it was much less unified in its general approach. The Polish school, founded by Florian Znaniecki, was much more restricted in its scope [Coser 1971: 164-165].

\section{CO-WORKERS AND INSTITUTIONAL ACHIEVEMENTS}

Paradoxically, the development of the Poznan School was affected by a lack of institutional frameworks for the development of sociology in Poland before WWI (separate university departments, journals and scholarly societies, etc.). Just as in France, Great Britain, Germany, Italy and the US, sociology was previously dealt with by scholars formally representing other disciplines of science; in Poland, since the late $19^{\text {th }}$ century the scholars included Ludwik Gumplowicz, Ludwik Krzywicki, Edward Abramowski, Kazimierz Kelles-Krauz, Zygmunt Balicki 
and Bolesław Limanowski [Kwilecki, Ziółkowski 1981: 8-9; Kwilecki 1988; Znaniecki Lopata 1965: xv]. Znaniecki was the first scholar in Poland and one of the first in Europe who managed to introduce sociological studies to a university and, later, established in Poznań academic circle which was able to create and suggest institutional cooperation framework to other Polish sociologists. This circle was based on his disciples as well as Polish sociologists enticed to cooperate and sociologists and representatives of related disciplines. Znaniecki tried to attract the already famous Bronisław Malinowski to Poznań but to no avail as some conservative professors at the Poznan University opposed the idea [Dulczewski 1984: 217-218].

There were several individuals who cooperated with Znaniecki but were not his students and who undoubtedly contributed to numerous achievements of the Poznań School. They ensured a high level of academic discussion, referring to the knowledge of the latest Polish and world sociological literature, what it is and how social phenomena should be examined. They also contributed to building up academic, institutional and personal relations which have survived till today in some forms (especially in Poznań) between sociology and other sciences like the law, history, ethnology or economy. Jan Stanisław Bystroń was an extremely important figure. The then doctor and professor at Jagiellonian University, he was initially planned to deliver lectures on ethnology and sociology in Poznań. In 1919-1926 he was head of the Department of Ethnology and Ethnography at the Poznań University and, at the same time, he conducted classes, including sociology, at Jagiellonian University. In Poznań, he was a very active member of the PIS and an editor of the sociology section of Ruch Prawniczy, Ekonomiczny i Socjologiczny (RPEiS) [Journal of Law, Economics and Sociology]; later on he was director of the Warsaw division of the PIS [Kowalski, Włodarek 1970: 39; Kwilecki, Ziółkowski 1981: 18-19]. Another important person in the Poznań sociological circle was Czesław Znamierowski, a professor of philosophy and theory of the law at the Faculty of Law and Economics. He developed an interest in sociology by attending Georg Simmel's lectures. For many years, he was editor in the section of sociological reviews in the RPEiS, for a shorter time he was deputy director at the PIS. His independence is best reflected in the methodological dispute with F. Znaniecki which escalated in the late 1920s [Kwilecki, Ziółkowski 1981: 20-21; Andreski 1986]. The development of sociology in Poznań was underpinned also by the presence of other scholars, among them the sociologically-oriented historian Kazimierz Tymieniecki [Kwilecki, Ziółkowski 1981: 21-22]. Attention should also be drawn to the contribution of Eileen Markley, an American scholar awarded a Master of Arts 
degree from Columbia University and a doctorate from University of Chicago who joined Znaniecki and Thomas in their work on The Polish Peasant [Dulczewski 1984: 203-204]. She came to Poznań as Znaniecki's wife, conducted classes at the university and was of great help in developing her husband's career, typing his manuscripts and proof-reading his works written in English.

In 1921, Znaniecki established in Poznań a scientific society named Instytut Socjologiczny [Institute of Sociology], independent from the university structures although related by the personnel and premises. It was the first institute of the type in Poland and the fifth-oldest in the world, after Paris, Brussels, Torino and Cologne [Polski Instytut Socjologiczny w Poznaniu... 1928]. In 1928, it became a national institution and was renamed Polski Instytut Socjologiczny. The Institute was effective in obtaining funds for its operations from the Science Department of the Ministry of Religious Denominations and Public Enlightenment, the authorities of the city of Poznan (research related to the imminent Polish General Exhibition, including a contest "What does Poznań mean to you?") or the authorities of the city of Lodz (research into workers' bios).

As the director of the PIS, F. Znaniecki involved his closest disciples in the institution's all activities and decision-making processes; he also delegated important tasks and functions. Most of his disciples gained considerable and invaluable research, academic, organizational and editorial experience. We can guess that as a result, they felt more responsible for the development of the Poznań School and forged a bond with Znaniecki.

The Institute's operations offered opportunities of regular insight into the latest achievements of other sociologists, undertaking new research, publishing their results and establishing new contacts.

The statutory responsibilities of the Institute included collecting and developing materials for sociological research. This was reflected in applying a method, typical of the Poznań School and consisting of collecting autobiographies from various social groups as a result of public contests. Znaniecki's disciples co-organized the contests, were the jurors, awarded selected works and surveyed them (by 1939, the PIS had collected more than 1,700 various autobiographies). This method connected with the assumptions underlying Znaniecki's sociological theory [see: Tacq 2007, Tacq 2011] and, for the first time ever, was employed in 1921 when the PIS held a contest "A worker's own life story" [Kwilecki 2011]. Another task handled by the PIS was publishing both academic works written in Polish (e.g. by Szczurkiewicz, Dobrzyńska-Rybicka, Duda-Dziewierz, Znaniecki, Chałasiński, Adamski) and in foreign languages (e.g. translation of Introduction to the Science of Sociology by Ernest W. Burgess and Robert Park) as well as 
(accompanied by introductions) selected autobiographical materials (e.g. works by Władysław Berkan and Jakub Wojciechowski, sent to the contest of 1921).

An important step in the establishment of the new sociological circle was entering cooperation with the editors of Ruch Prawniczy i Ekonomiczny [Journal of Law and Economics], a scientific journal published in Poznań since 1921 and renamed in 1925 Ruch Prawniczy, Ekonomiczny i Socjologiczny [Journal of Law, Economics and Sociology]. Initially, in the new section, book reviews and bibliography reviews of newly published Polish and foreign sociological books prevailed. The authors of the reviews published in the first issue of the renamed "Journal" included Bystron, Znamierowski, Błachowski, Szczurkiewicz [Kwilecki, Ziółkowski 1981: 11]. The RPEiS has been published until today. Its characteristics continued from the Interwar Period, include focusing on the latest practical issues related to the three areas specified in the journal's title. The published works include Znaniecki's "Początki myśli socjologicznej" ["The Origins of Sociological Thought"] (1928), "O szczeblach rozwoju społecznego" ["The Rungs of Social Evolution"] (1930), "Socjologiczne podstawy ekologii ludzkiej" ["The Sociological Foundations of Human Ecology"] (1938), "Stan obecny technologii społecznej" ["The Present State of Social Technology"] (1939) and Szczurkiewicz's "Zasadnicze stanowiska socjologów w ujmowaniu grupy społecznej” ["Sociologists' major definitions of social groups"] (1935) and "Moda na socjologie" ["Sociology en vogue"] (1937).

The first issue of Przeglad Socjologiczny [Sociological Review], published in April 1930 by the PIS, can be compared to the emergence of L'Année Sociologique in French sociology [see: Besnard 1979]. The quarterly was the first journal in the country dedicated exclusively to sociology. It was edited by sociologists Znaniecki (editor in chief), Szczurkiewicz (secretary) and Chałasiński, supported by psychologist Błachowski and educator Jaxa-Bykowski. All of them had ties with the Poznań University. While the journal established by É. Durkheim published mostly his works and works of his disciples, Przeglad Socjologiczny integrated various circles. This is how the editors' committee defined its goals:

Our intention is to transform this journal into a magazine not only at the disposal of the Institute but Polish sociological thought in general, to provide a forum for opinions not only of a local group but all sociological trends in Poland. (...) To establish a centre of Polish sociological thought, to maintain contacts with progressing foreign sociology and, finally, to propagate interest in sociology and thus contribute to developing Polish culture in general" [Od Redakcji 1930: 1-2].

The authors of the articles included in volume 1 of Przeglad Socjologiczny were both "Posnanians" (C. Znamierowski, J. Paczoski, F. Znaniecki, J. Krzy- 
żanowski) and representatives of other academic centres: Warsaw (represented by L. Krzywicki), London (B. Malinowski), Krakow (J.S. Bystroń), Brno (E. Blaha). The other authors, sociologists and representatives of different disciplines, whose articles were published in the subsequent issues, included (from the Poznań School): W. Adamski, J. Chałasiński, J. Piotrowski, J. Szczepański, T. Szczurkiewicz and, from other universities, N. Assorodobraj, S. Czarnowski, W. Grabski, A. Hertz, W. Kula, S. Ossowski, H. Radlińska, P. Rybicki, S. Rychliński. The reviews of works published in Poland and abroad (written chiefly in English, German and French) were provided by T. Abel, W. Okiński, J. Obrębski, E. Markley-Znaniecki, J. Szczepański, J. Orchowski, F. Karpiński, J. Chałasiński. A list of all the articles and reviews published in Przeglad Socjologiczny was presented in its jubilee issue from 2010 [Spisy treści przedwojennych tomów... 2010: 141-160].

The Institute's willingness to maintain cooperation with other sociological institutions and societies in Poland was demonstrated in 1931 by organizing in Poznań the first rally of Polish sociologists; at F. Znaniecki's request, the event was chaired by Ludwik Krzywicki, a doyen among Polish sociologists [Dulczewski 1984: 243]. Sixty years after establishing a department of sociology in Poznań, Andrzej Kwilecki and Janusz Ziółkowski [1981: 14] wrote that another characteristic of Znaniecki's school was to maintain regular contacts with representatives of world sociology. Znaniecki was member of numerous international scholarly assemblies including the International Institute of Sociology established in Paris [Martin, Keck, Marcel 2004: 3]. There was a special type of cooperation between the Poznan school and centres of sociology in the United States. This held true specifically for contacts with Columbia University where Abel was employed, Znaniecki's student in the first years following the establishment of the Sociological Seminar. Later, he paid numerous visits to Poland; he also contributed to William F. Russell's and Robert M. MacIver's visits to Poznań while the PIS received from Carnegie Corporation in New York funds for studying Polish-German relations in Upper Silesia [Dulczewski 1984: 226-227, 246]. During his trips to the United States, F. Znaniecki took part in methodological debates which tended to greatly polarise the scholars [Hałas 2010: 179-180; Abel 1996: 40-41; Tacq 2007], during which he defended his vision of sociology as a cultural science, presented in The Method of Sociology (1934), originally printed by an American publisher. 


\section{AND BEYOND}

"When the leader goes, the school soon fades out" [Harvey 1987: 269]. Due to the outbreak of WWII in 1939, F. Znaniecki had to change his plans and did not return to Poland after his stay at Columbia University. Just as Robert E. Park's departure in 1933 affected the loss of inner cohesion of the Chicago School [Harvey 1987: 254], the events in 1939 contributed to withholding Znaniecki's and his colleagues' intense academic activity. From that moment on, the Poznan School belonged to the past, however, many important institutions established by Znaniecki continued their operations in Poland. In 1945, in a letter to the dean of the Poznań University and in a private letter to Szczurkiewicz, Znaniecki handed over management of the Department of Sociology to his first junior assistant in Poznań [Wesołowski 1976: 32-33]. At the same time, Szczurkiewicz participated in establishing a department of sociology in Torun. Back in 1935, Chałasiński, another disciple and close collaborator of Znaniecki, moved to Warsaw where he managed Przeglad Socjologiczny. After WWII, he established a robust centre of sociology in Lodz where he also moved the PIS seat and the editors of Przeglad Socjologiczny [Ruszczewska 1990: 219-220]. For many years, Szczepański had worked in Lodz before he was transferred to Warsaw; in 1966-1970 he was chairman of the International Sociological Association. Kowalski also had to look for employment in Lodz but, after a short time, he returned to Poznań. There, academic work was continued by Józef Burszta and Dulczewski, Znaniecki's students before WWII who wrote their master's theses under Szczurkiewicz's supervision, in 1945 and 1947, respectively [Kwilecki, Ziółkowski 1981: 28-29]. As for the other disciples of the author of The Method of Sociology in the Poznan period, they moved to the universities in Lublin (Mirek) and Warsaw (Piotrowski) and, outside of Poland, in New York, US (Abel and Gidyński) and in Reading, UK (Stanisław Andrzejewski [Andreski]) [a larger list of Znaniecki's closer and less familiar students who continued their academic careers is provided by Dulczewski 1984: 231-234].

F. Znaniecki remained in the United States for the rest of his life. By 1940, he worked at Columbia University and for the subsequent ten years at the University of Illinois in Urbana-Champaign (since 1950 as the University's professor emeritus). In the latter location, he conducted classes for advanced undergraduate and graduate students, encouraging them (the way he did in Poznań) to solve academic issues of his interest at that time, for example related to his work on The Social Role of the University Student (1994) and Modern Nationalities (1952) [Dulczewski 1984: 283-188]. However, he was not a formal supervisor of ma- 
ster's or doctoral theses: "As an educator in charge of his students' works and the architect of a school of sociology, Znaniecki 'had his fill' during the twenty years of his teaching and educating activity in Poland. In his early 60s, (...) he decided to focus primarily on his own academic and scholarly work which, as he once said, would be enough for three lifetimes", wrote Dulczewski [1984: 286]. At that time, he was in touch with Thomas, MacIver, Becker as well as new American researchers and his disciples from Poznan living in the US: Abel and Gidyński. The subsequent academic achievements and the letters written to Znaniecki by two American sociologists: Max Kaplan and Robert Bierstedt make them Znaniecki's disciples from that time [Dulczewski 1984: 298]. Gidyński characterised Bierstedt as follows: "Bierstedt speaks about you with enthusiasm eerily reminiscent of the enthusiasm of your old Poznań disciples" [as quoted in: Dulczewski 1984: 298]. Bierstedt dedicated one of his books to Znaniecki [see: Bierstedt 1968]. In private, he was a son-in-law of R. MacIver who was a close friend of F. Znaniecki. At the same time, the co-author of The Polish Peasant corresponded with his disciples from the Poznan School and other sociologists in Poland [e.g. Listy Eileen i Floriana Znanieckich ... 2011]. He enjoyed recognition in the United States; a case in point is speeches during a celebration held at the University of Illinois related to his retirement, sent over or delivered personally by R.K. Merton (who called F. Znaniecki a "Dean of the World's Sociologists"), E.S. Bogardus, E.W. Burgess, R. MacIver, H. Blumer, F.E. Frazier, L. Wirth, E.A. Ross, P.A. Sorokin, K. Young, T.C. McCormick, T. Parsons and H. Becker [Dulczewski 1984: 302-304]. In 1954, F. Znaniecki was president of the American Sociological Association.

As for the time after 1945, one more scholar needs to be mentioned: Jerzy Zubrzycki did not study in Poznań, he referred to himself as Znaniecki's disciple. He was one of the creators of the Australian school of multiculturalism who followed the rule of a humanistic coefficient in his research and resorted to autobiographical materials. Znaniecki was a promoter of Zubrzycki's doctoral thesis defended in 1954 in London [Babiński, Dulczewski, Szczepański 1998].

Despite the geographic dispersion and political difficulties in the development of sociology in Poland in the first years after the war, many disciples of Znaniecki shared with the subsequent sociologists their knowledge of establishing the PIS; in their scholarly work, references to the Institute were made by scholars whose promoters included Chałasiński (e.g. Kłoskowska), Szczurkiewicz (e.g. Ziółkowski, Krzykała), Dulczewski (e.g. Leoński), Kowalski (e.g. Markiewicz) or Zubrzycki (e.g. Smolicz). This was reflected in the devotion to the assumption of humanist sociology, adoption of the principle of humanistic 
coefficient, building the "bottom-up" sociological theory (subjective actions of individuals as a reflection of objective norms) or in examining the mutual relations between an individual's actions and the social structure. They frequently dealt with issues developed by the Poznań School: culture defined as an axionormative order of various social systems (roles, groups, societies, civilisation), a nation and ethnic relations, migration and social mobility, the city and space as well as education.

The methodological continuation manifested itself in the attitude towards carrying out qualitative research [Konecki, Kacperczyk, Marciniak 2005], especially making use of personal documents and autobiographies [e.g. Czyżewski, Rokuszewska-Pawełek 1989a, 1989b, 1990; Czyżewski, Piotrowski, Rokuszewska-Pawełek 1996; Kaźmierska 1999; Rokuszewska-Pawełek 1996; Rokuszewska-Pawełek 2002]. The method of inspired memoirs (Polish pamiętniki), initiated in Poznań and developed by Abel [1938], Dulczewski [2000], Chałasiński [1981] and Szczepański [1981], to name a few, soon became a trademark of the entire Polish sociology [see: Bertaux, Kohli 1981: 221; in the Interwar Period, it was used also by sociologists representing other theoretical orientations, e.g. Krzywicki and Grabski]. Over time, especially after WWII, writing autobiographies as part of contests organized by various institutions, editors and social organizations gained popularity in Poland, involving tens of thousands of people [Kaźmierska 2012: 19-26]. Frequently, in contest proclamations and the subsequent analyses of autobiographies, references were made to the achievements of the PIS. To mention an exemplary initiative, in 1981, referring to PIS' enterprise from sixty years before, the employees of the Institute of Sociology of Adam Mickiewicz University in Poznań organized a national contest on workers' autobiographies [see: Szafran-Bartoszek, Kiełczewska, Kwilecki, Leoński, Wawruch 1996]. Another group included sociologists from the Poznań-based Institute for Western Affairs who made a name for themselves by collecting three times (in 1956, 1966 and 1970) memoirs of settlers and their children living in Recovered Territories (West and North of Poland) that became part of Poland after WWII [e.g. Dulczewski, Kwilecki 1970]. What is more, in Warsaw, Wrocław, Krakow, Lublin, Kielce and in many other cities, towns and even villages, the locals' stories were collected as a reference to the "What does Poznań mean to you?" contest. In the city of Poznań, Znaniecki's pioneering research was repeated twice: in 1964 and 1994 [see: Znaniecki, Ziółkowski 1984; Cichocki, Podemski 1999].

The conferences and publications, e.g. accompanying Znaniecki's birthday (1982) or the centenary of The Polish Peasant (2018) commemorated the 
former masters and academic genealogies among the successive generations of sociologists. Evidence of the myth of the Poznań School, cultivated by Znaniecki's disciples and friends, his continuators and the interpreters of his ideas, is the fact of registering in 1989 in Poznań Florian Znaniecki Scientific Foundation. Members of the first Council included Bierstedt, Dulczewski, Kłoskowska, Leoński, Merton, Smolicz, Szczepański, Ziółkowski and Zubrzycki.

\section{CONCLUSIONS AND SUGGESTED AREAS OF NEW RESEARCH}

The establishment of the Poznań School of Sociology stemmed from a confluence of events. Firstly, just like in Durkheim's School, there were favourable conditions for sociology to become a separate academic discipline. Znaniecki was the first scholar who could educate in Poland students with a major in sociology. Bearing in mind the selected elements characteristic of schools of thought [Muszyński 1995: 64-66], some other conclusions can be drawn. The Poznań School of Sociology passed through several stages: the development of the founder-leaders' personality (before 1920), selection and education of the disciples (since 1920), the heyday and recognition (since the mid-1920s until 1939), the geographic spread (since the 1930s until 1939, possibly the early 1950s in relation with Znaniecki's former disciples starting work in new institutions) and the decline (since 1939). Just as in Bordeaux, in Poznan the master-disciples relation was forged. However, the sociologists educated by F. Znaniecki still managed to become self-reliant scientists; the process started in the 1930s as demonstrated by the development of Chałasiński's academic career. On the other hand, the relations between Znaniecki and the academics from his generation (Bystron and Znamierowski) were more like a partnership and were reminiscent of the relations between the personalities of the early Chicago School.

Members of the Poznań School were certain of their proximity when it comes to the adopted way of practicing sociology and tended to call it a "school", unlike in the centre established by A. Small [the notion of the "Chicago School" is a retrospective construction, see: Harvey 1987: 255-260]. However, the Poznan School did not operate in isolation: its members initiated and fostered cooperation between sociologists representing various paradigms, they were interested in the achievements of Polish and foreign research centres and strived to publish them in their scientific journals. What is more, the opinions of the author of The Method of Sociology could have been criticised both by Znaniecki's disciples and colleagues as exemplified by his methodological dispute with Znamierowski. For these reasons, it is hard to conclude that the Poznań School was of closed or 
even sect-like nature as sometimes schools of thought are criticized for en globe [see: Hirschhorn 2018; Harvey 1987: 247-249]. In the case of Znaniecki's School, the concept of a "school" can be used both as a historical category referring to a real scientific community and - with respect to a myth surrounding the school - as a label making the group and its concept of sociology more visible [see: Hirschhorn 2018].

Secondly, just as in Bordeaux, the school was originated by a scientist who suggested an original sociological theory based on solid philosophical foundations. Of importance was also the fact that when Znaniecki created the department of sociology, his views had been scientifically legitimised in Poland following publications of his articles and books, including those which were published before 1914. The attractiveness of the Poznan School consisted also in the fact that it combined strictly theoretical and empirical research thus referred to Znaniecki's experience from his work on The Polish Peasant. It would be interesting to know to what extent Znaniecki's disciples referred to his publications from before cooperation with W.I. Thomas. We do know that The Polish Peasant made Znaniecki a world-famous sociologist, it shadowed the significance of his former works [Hałas 2006: 262; Wiley 2007].

Thirdly, we should appreciate the fact that Znaniecki knew very well the other schools of sociology, as a result of reading foreign works and his visits to universities in Switzerland, France and the US. His gradual conversion from a philosopher into a sociologist started abroad and was not complete until his stay in Poznań. In Paris and Chicago, he had an opportunity to observe sociologists forming specific academic or institutional structures. In 1920, he faced an extraordinary opportunity of creating a school that could develop as dynamically as the establishments he observed but one that would adopt his own scientific paradigm. It seems that a comparison of the achievements of Znaniecki's school from 1920-1939 with the Chicago School and Durkheim's School with respect to their operations, organisation [see: Béra et al. 2014], the adopted theoretical and methodological assumptions coupled with the subjects of the research and, finally - creating their own traditions and the subsequent evolutions there of [see: Cuin, Hervouet 2018; Harvey 1986] is among the most interesting areas of exploration form the point of view of contemporary scholars.

It is worth investigating the previously neglected French influence on the Poznań School. While Znaniecki and Durkheim had different sociological assumptions, undoubtedly the French sociologist was an important point of reference for the author of The Method of Sociology (treating one's view of sociology as a programme of sociology per se, care for creating an institutional framework 
for the discipline's growth, shaping sociology-defining disciples and at the same time, retaining their scholarly independence, involvement in the country's public life, carrying out empirical research etc. [see: Mosbah-Natanson 2008; Cuin 1998]). What is more, Znaniecki knew the views of numerous French thinkers including Bergson and those engaged in disputes with the creator of the Bordeaux School. Of special importance seems to be the way in which Znaniecki's school was perceived in France in the Interwar Period. Were the views represented in Poznań supported in France where e.g. there were problems with accepting analytic philosophy? [Pudal 2004: 72] The question is worth answering, at the same time drawing attention to the European roots of Znaniecki's philosophical and, later, sociological theory. As an active intellectual at American universities, he contributed to an influence of the European thought on the development of the American social theory [Coser 1977: 547-549; Hałas 2010: 184-185; Chałasiński 1989: 19].

Fourthly, the school could be established owing to Znaniecki's ability to create a circle of scholars involved in undertaking shared institutional ventures. The establishment of the PIS with its own journal and a publishing house, capable of raising funds for new scientific research most certainly reinforced Znaniecki's and his disciples' position in the other sociological circles in Poland [see: Wincławski 2009: 43]. Just like in Durkheim's case, the institutional and academic development of Znaniecki's school was largely influenced by its students. Educating a relatively large number of students who could be entrusted with specific tasks may be deemed a reason for the creation and dynamic operations of a school of sociology in Poznań. When, during his permanent stay in the US, he practically ceased to undertake supervising responsibility for master's or doctoral theses, it was next to impossible to recreate the master-disciples arrangement from the Interwar Period. There are many reasons why at the University of Illinois he failed to create "the Poznań School 2" [see: Coser 1977: 557-558] and it could be of interest to contemporary scholars. The venue where Znaniecki's school was established and operated was Poznań, at a time when the Polish state made a comeback to the map of Europe. It was created by a relatively young scholar with impressive achievements and international experience who, following patriotic motives, returned to Poland with an intention of establishing sociological studies at a Polish university.

Znaniecki's creation of the school poses questions asked throughout this article. Most certainly, the reception of Znaniecki's work deserves in-depth analyses. The question is about the coherence of the Poznan School and the extent to which his disciples took over their master's views and modus operandi. The 
goal would be to show also the mutual impact between the specific members of the Poznań School. For example, Stanisław Kowalski [1987: 176] wrote that the team members' research ambitions were nurtured by Znaniecki's works published in short intervals but also by works of older and younger colleagues: Józef Chałasiński, Władysław Okiński, Jan Szczepański. Just like in Durkheim’s School, many representatives of the Poznań School boasted notable achievements that could not even be summarised in this article. To learn about the sources of inspiration of these scholars, their mutual influences and uniqueness of their own views would provide information about the nature of the Poznan School. This, in turn, would allow to better understand the development of Polish sociology, its various trends and traditions. The questions pertaining to the different schools of sociology are in fact questions about how much we can have in common and what we can do with that knowledge in order to better analyse various social phenomena.

\section{REFERENCES}

Abel Teodor. 1996. O Florianie Znanieckim. Wybór z dziennika. Wybrała, przełożyła, opatrzyła wstępem i przypisami E. Hałas. Lublin: Norbertinum. [English version: Abel Theodore. 2001. The Columbia circle of scholars. Selections from the journal (1930-1957). Edited and introduced by E. Hałas. Frankfurt am Main: Peter Lang.]

Abel Theodore. 1938. Why Hitler came into power. New York: Prentice-Hall.

Andreski Stanislav. 1986. Florian Znaniecki and Czesław Znamierowski: Complementary in opposition. In: A commemorative book in honor of Florian Znaniecki on the centenary of his birth. Z. Dulczewski (ed.), 31-36. Poznań: Uniwersytet im. Adama Mickiewicza.

Babiński Grzegorz, Zygmunt Dulczewski, Jan Szczepański. 1998. „Opinie o działalności i dorobku naukowym prof. Jerzego Zubrzyckiego". Ruch Prawniczy, Ekonomiczny i Socjologiczny 3-4: 487-493.

Benisz Wojciech. 2013. "Ekologia ludzka Znanieckiego a ekologia społeczna szkoły chicagowskiej - podobieństwa, różnice, nawiązania". Roczniki Historii Socjologii 3: 111-125.

Béra Matthieu. 2014. Durkheim à Bordeaux, 1887-1902. Bordeaux: Éditions Confluences.

Bertaux Daniel, Martin Kohli. 1984. "The life story approach: A continental view". Annual Review of Sociology 10: 215-237.

Besnard Philippe. 1979. "La formation de l'equipe de l'Année sociologique". Revue française de sociologie 20(1): 7-31.

Bierstedt Robert. 1969. Introduction. In: Florian Znaniecki on humanistic sociology. Selected papers. R. Bierstedt (ed.), 1-34. Chicago: University of Chicago Press.

Bucholc Marta. 2016. Sociology in Poland. To be continued? London: Palgrave Macmillan.

Bulmer Martin. 1984. The Chicago School of sociology. Institutionalization, diversity, and the rise of sociological research. Chicago and London: The University of Chicago Press.

Chalasiński Józef. 1981. The life records of the young generation of Polish Peasants as a manifestation of contemporary culture. In: Biography and society. The life history approach in the 
social sciences. D. Bertaux Daniel (ed.), 119-132. London - Beverly Hills: Sage \& International Sociological Association.

Chałasiński Józef. 1989. Znaniecki: The Polish sociologist, the American sociologist. In: The humanistic sociology of Florian Znaniecki. Polish period 1920-1939. A. Kwilecki, B. Czarnocki (eds), 15-24. Warszawa-Poznań: Polish Scientific Publishers.

Cichocki Ryszard, Krzysztof Podemski. 1999. Miasto w świadomości swoich mieszkańców. Poznań: Wydawnictwo Fundacji Humaniora.

Clark Terry N. 1968. "Émile Durkheim and the institutionalization of sociology in the French university system”. European Journal of Sociology / Archives Européennes de Sociologie 9: 37-71.

Coser Lewis A. 1977. Masters of sociological thought: Ideas in historical and social context. New York: Harcourt Brace Jovanovich.

Cuin Charles-Henry, Ronan Hervouet. (eds.) 2018. Durkheim aujourd'hui. Paris: Presses Universitaires de France.

Cuin Charles-Henry. (ed.) 1998. Durkheim d'un siècle à l'autre, lectures actuelles des "Règles de la méthode sociologique". Paris: Presses Universitaires de France.

Czarnocki Bohdan, Andrzej Kwilecki. 1989. Introduction. In: The humanistic sociology of Florian Znaniecki. Polish period 1920-1939. A. Kwilecki, B. Czarnocki (eds), 7-11. Warszawa-Poznań: Polish Scientific Publishers.

Czyżewski Marek, Alicja Rokuszewska-Pawełek. 1989a. Analiza autobiografii Rudolpha Hössa. Część I. Kultura i Społeczeństwo 2: 35-65.

Czyżewski Marek, Alicja Rokuszewska-Pawełek. 1989b. Analiza autobiografii Rudolpha Hössa. Część II. Kultura i Społeczeństwo 3-4: 163-181.

Czyżewski Marek, Alicja Rokuszewska-Pawełek. 1990. Analiza autobiografii Rudolpha Hössa. Część III. Kultura i Spoleczeństwo 1: 119-135.

Czyżewski Marek, Andrzej Piotrowski, Alicja Rokuszewska-Pawełek. (eds.) 1996. Biografia a tożsamość narodowa. Łódź: Katedra Socjologii Kultury Uniwersytetu Łódzkiego.

Dulczewski Zygmunt. (ed.). 1986. A commemorative book in honor of Florian Znaniecki on the centenary of his birth. Poznań: Uniwersytet im. Adama Mickiewicza.

Dulczewski Zygmunt. 1984. Florian Znaniecki. Życie i dzieło. Poznań: Wydawnictwo Poznańskie. [English version: Dulczewski Zygmunt. 1992. Florian Znaniecki. Life and work. Poznań: Wydawnictwo Naukom].

Dulczewski Zygmunt. 2000. O Florianie Znanieckim. Poznań: Fundacja Naukowa im. Floriana Znanieckiego, ARP „Promocja 21”.

Dulczewski Zygmunt, Andrzej Kwilecki (eds.). 1970. Pamiętniki osadników Ziem Odzyskanych. Poznań: Wydawnictwo Poznańskie.

Halas Elżbieta. 2000. Florian Znaniecki's sociological theory and the challenges of 21st century Frankfurt am Main: Peter Lang.

Halas Elżbieta. 2006. "Classical cultural sociology: Florian Znaniecki’s impact in a new light". Journal of Classical Sociology 6(3): 257-282.

Halas Elżbieta. 2010a. From the Methodological Note to the Method of Sociology: Florian Znaniecki's role in the methodological debate in interwar American sociology. In: Transatlantic voyages and sociology. The migration and development of ideas. C. Schrecker (ed.), 177-191. Surrey: Ashgate.

Halas Elżbieta. 2010b. Towards the world culture society. Florian Znaniecki's culturalism. Frankfurt Am Main: Peter Lang. 
Harvey Lee. 1986. "The myths of the Chicago School”. Quality and Quantity 20: 191-217.

Harvey Lee. 1987. "The nature of 'schools' in the sociology of knowledge: The case of the 'Chicago School"'. Sociological Review 35(2): 245-278.

Hirschhorn Monique. 2018. "L'école en sociologie: Catégorie, objet, étiquette". Revue d'histoire des sciences humaines 31: 153-170.

Kaźmierska Kaja. 1999. Doświadczenia wojenne Polaków a ksztaltowanie tożsamości etnicznej. Analiza narracji kresowych. Warszawa: Wydawnictwo IFiS PAN.

Kaźmierska Kaja. 2012. Wprowadzenie [do rozdziału I: Szkoła Chicago]. In: Metoda biograficzna w socjologii. Antologia tekstów. K. Kaźmierska (ed.), 17-30. Kraków: Nomos.

Konecki Krzysztof T., Anna M. Kacperczyk, Lukasz T. Marciniak. 2005. "Polish qualitative sociology: The general features and development". Forum Qualitative Sozialforschung / Forum: Qualitative Social Research 6(3), Art. 27.

Kowalski Stanisław, Jan Włodarek. 1970. "Pięćdziesiąt lat socjologii poznańskiej”. Ruch Prawniczy, Ekonomiczny i Socjologiczny 2: 39-65.

Kowalski Stanisław. 1987. "Florian Znaniecki w świetle monografii Zygmunta Dulczewskiego". Ruch Prawniczy, Ekonomiczny i Socjologiczny 1: 175-186.

Kraśko Nina. 1996. Instytucjonalizacja socjologii w Polsce 1920-1970. Warszawa: Wydawnictwo Naukowe PWN.

Kraśko Nina. 2010. Instytucjonalizacja socjologii w Polsce 1970-2000. Warszawa: Wydawnictwa Uniwersytetu Warszawskiego.

Kubera Jacek, Lukasz Skoczylas, Żaneta Szerksznis. 2017. Towards a revival of Znaniecki's achievements? Florian Znaniecki's theory and methodology: Their presence in citation databases and possible applications in contemporary migration studies. In: Contemporary migrations in the humanistic coefficient perspective. Florian Znaniecki's thought in today's social science research. J. Kubera, Ł. Skoczylas (eds.), 215-249. Frankfurt am Main: Peter Lang.

Kwaśniewicz Wladysław. 2001. “Co pozostaje żywe z tradycji polskiej socjologii?”. Ruch Prawniczy, Ekonomiczny i Socjologiczny 4: 229-250.

Kwilecki Andrzej. 2011. "Pionierskie przedsięwzięcia badawcze poznańskiej socjologii 1921-1922”. Ruch Prawniczy, Ekonomiczny i Socjologiczny 2: 323-331.

Kwilecki Andrzej, Janusz Ziółkowski. 1981. Socjologia w Poznaniu w latach 1920-1980. In: 60 lat socjologii poznańskiej. A. Kwilecki (ed.), 7-54. Poznań: Uniwersytet im. Adama Mickiewicza w Poznaniu.

Kwilecki Andrzej. 1988. "Tradycje socjologii polskiej”. Ruch Prawniczy, Ekonomiczny i Socjologiczny 2: 237-262.

Lisiecki Stanisław, Jacek Kubera (eds.). 2016. Podpatrywanie miasta. Miasto w socjologii poznańskiej 1920-2000. Poznań: Wydawnictwo Nauka i Innowacje.

Lisiecki Stanisław. 2015. "Florian Znaniecki i Janusz Ziółkowski. O tradycji i kontynuacjach badań nad wartościowaniem przestrzeni miasta". Ruch Prawniczy, Ekonomiczny i Socjologiczny 1: 13-26.

"Listy Eileen i Floriana Znanieckich do Józefa Chałasińskiego z lat 1933-1960 (Opracował Włodzimierz Wincławski, listy p. Znanieckiej tłumaczyła Lucyna Stetkiewicz)". 2011. Roczniki Historii Socjologii 1: 159-168.

Markiewicz-Lagneau Janina. 1982. "Florian Znaniecki, sociologue de l'action sociale et de la méthode analitique". Revue française de sociologie 23(2): 171-193.

Martin Olivier, Frédéric Keck, Jean-Christophe Marcel. 2004. "France-États-Unis: Influences croisées en sciences humaines". Revue d'Histoire des Sciences Humaines 2: 3-12. 
Mirek Franciszek. 1928. Elementy społeczne parafji rzymsko-katolickiej. Wstęp do socjologii parafji. Poznań: Fiszer i Majewski, Księgarnia Uniwersytecka.

Mosbah-Natanson Sébastien. 2008. "Internationalisme et tradition nationale: Le cas de la constitution de la sociologie française autour de 1900". Revue d'Histoire des Sciences Humaines 18(1): 35-62.

Mucha Janusz. 2009. „Socjologia w Europie Środkowo-Wschodniej czy socjologia wschodnioeuropejska?". Przegląd Socjologiczny 2: 9-31.

Muszyński Zbysław. 1995. „Siedem cech głównych szkoły naukowej”. Filozofia Nauki 1-2(9-10): 63-67.

„Od Redakcji”. 1930. Przeglad Socjologiczny 1: 1-2.

„Polski Instytut Socjologiczny w Poznaniu jest piątym na świecie. Wywiad 'Gazety Poznańskiej i Pomorskiej’ z założycielem i dyrektorem Instytutu prof. dr. Florjanem Znanieckim”. 1928. Gazeta Poznańska i Pomorska 216 (December 8): 3.

Pudal Romain. 2004. "La difficile réception de la philosophie analytique en France". Revue d'Histoire des Sciences Humaines 2: 69-100.

Rokuszewska-Pawełek Alicja. 1996. „Miejsce biografii w socjologii interpretatywnej. Program socjologii biografistycznej Fritza Schützego". ASK, 1: 37-54.

Rokuszewska-Pawełek Alicja. 2002. Chaos i przymus. Trajektorie wojenne Polaków - analiza biograficzna. Łódź: Wydawnictwo Uniwersytetu Łódzkiego.

Ruszczewska Violetta. 1990. „Ośrodki i instytucje socjologii polskiej w pierwszych latach po drugiej wojnie światowej”. Ruch Prawniczy, Ekonomiczny i Socjologiczny 3-4: 215-232.

„Spisy treści przedwojennych tomów 'Przeglądu Socjologicznego'”. 1930. Przegląd Socjologiczny 1: 141-160.

Szacki Jerzy. 1975. “'Schools' in sociology”. Social Science Information 12(4): 173-182.

Szafran-Bartoszek Aurelia, Ewa Kiełczewska, Andrzej Kwilecki, Jacek Leoński, Krzysztof Wawruch. 1996. Robotnicze losy: Życiorysy własne robotników pisane w latach konfliktu 1981-1982. Vol. 1 and vol. 2. Poznań: Wydawnictwo Naukowe UAM.

Szczepański Jan. 1981. The use of autobiographies in historical social psychology. In: Biography and society. The life history approach in the social sciences. D. Bertaux (ed.), 225-234. London - Beverly Hills: Sage \& International Sociological Association.

Tacq Jacques. "Causality in qualitative and quantitative research". Quality \& Quantity 45: 263-291.

Tacq Jacques. 2007. "Znaniecki's analytic induction as a method of sociological research". Polish Sociological Review 2(158): 187-208.

Wallis Aleksander. 1989. Znaniecki's sociological foundations of human ecology. In: The humanistic sociology of Florian Znaniecki. Polish period 1920-1939. A. Kwilecki, B. Czarnocki (eds), 80-86. Warszawa-Poznań: Polish Scientific Publishers.

Wesołowski Aleksander. 1976. „Działalność organizacyjno-naukowa i dydaktyczna Tadeusza Szczurkiewicza”. Ruch Prawniczy, Ekonomiczny i Socjologiczny 1: 29-40.

Wiley Norbert. 2007. "Znaniecki's key insight: The merger of pragmatism and neo-Kantianism". Polish Sociological Review, 2(158): 133-143.

Winclawski Włodzimierz. 2009. „Dzieje socjologii polskiej (1860-1939) w zwierciadle bibliometrii (Próba weryfikacji metody)". Przegląd Socjologiczny 2: 33-52.

Wincławski Włodzimierz. 2012. „Wstep do socjologii Floriana Znanieckiego - wyzwanie rzucone polskiej socjologii i jego następstwa (dziewięćdziesiąta rocznica publikacji dzieła)". Roczniki Historii Socjologii 2: 5-18. 
Wojtczak Leszek et al. 1992. Bunty i stużebności uczonego: profesor Józef Chałasiński. Łódź: Wydawnictwo Uniwersytetu Łódzkiego.

Znaniecki Florian, Janusz Ziółkowski. 1984. Czym jest dla ciebie miasto Poznań? Dwa konkursy: 1928/1964. Warszawa-Poznań: Państwowe Wydawnictwo Naukowe.

Znamierowski Czesław. 1931. „Pierwsza konferencja socjologów polskich”. Ruch Prawniczy, Ekonomiczny i Socjologiczny 2: 571-575.

Znaniecki Lopata Helena. 1965. Florian Znaniecki - his life. In: F. Znaniecki, Social relations and social roles: The unfinished systematic sociology, xiii-xix. San Fransico: Chandler Publishing Company.

Znaniecki Lopata Helena. 1976. "Florian Znaniecki - creative evolution of a sociologist". Journal of the History of the Behavioral Sciences 12(3): 203-215.

Jacek Kubera

\section{NIE TYLKO CHLOP POLSKI. \\ POZNAŃSKA SZKOLA SOCJOLOGII ZNANIECKIEGO JAKO PROBLEM SOCJOLOGICZNY I BADAWCZY}

Streszczenie

Podobnie jak Émile Durkheim w Bordeaux, tak Florian Znaniecki w Poznaniu stworzył własną szkołę socjologiczną. Pojęcie to odnosi się w tym przypadku do dydaktycznej, badawczej, naukowej i organizacyjnej działalności F. Znanieckiego i jego współpracowników w latach 1920-1939 podejmowanej przez nich przede wszystkim w ramach dwóch niezależnych instytucji: Uniwersytetu Poznańskiego i założonego w Poznaniu Polskiego Instytutu Socjologicznego. Poznań stanowił centrum działalności szkoły, jednak jej oddziaływanie było dalece szersze. Przejawiało się $\mathrm{w}$ inicjatywach integrujących różne środowiska socjologiczne w Polsce, utrzymywaniu kontaktu z innymi ośrodkami akademickimi w Europie i w Stanach Zjednoczonych, a także w podejmowaniu pracy naukowej lub zakładaniu własnych instytutów badawczych w nowych miejscach w Polsce i poza jej granicami przez wychowanków F. Znanieckiego.

Artykuł wskazuje na wybrane najważniejsze cechy poznańskiej szkoły socjologicznej, do których zaliczyć można przyjęcie reprezentowanego przez F. Znanieckiego poglądu na przedmiot socjologii oraz wytworzenie się bliskiej więzi między nim („Mistrzem”) a jego uczniami i współpracownikami. W końcowej części artykuł przedstawia niektóre szczegółowe kwestie, których wyjaśnienie pozwoliłoby lepiej zrozumieć charakter rozwoju szkoły Znanieckiego, a w szerszym ujęciu - socjologii polskiej i jej związków z socjologią europejską i amerykańską.

Słowa kluczowe: szkoła socjologiczna, historia socjologii, Florian Znaniecki, socjologia polska, Poznań 